\title{
Örgütlerde Katılımsız Yönetim Sorununu: Kavramsal Bir Çalışma
}

\author{
The Problem of Non-participation Management in Organizations: A \\ Conceptual Study
}

\section{Öz}

Bu çalışmada, örgütlerde ortaya çıkan katılımsız yönetim sorunu ile ilgili kavramsal bir çerçeve sunulmaya çalışılmıştır. Bu amacı gerçekleştirmek için katılımsız yönetim sorunu, türleri, nedenleri, sonuçları ve önlenmesi için yapılması gerekenlere değinilmiştir. Çalışma sonuçlarına göre, işgörenleri yönetime dâhil etmeme, yetki devri yapmama, personeli güçlendirmeme ve örgütsel demokrasinin olmayışı katılımsız yönetimin en önemli veçheleridir. Katılımsız yönetim sorununun motivasyon düşüklüğg̈, tükenmişlik, çalışma ortamının bozulması, verim ve performans kaybı, yönetsel etkinliğin azalması, değişime direncin artması, örgütsel bă̆hlliğın azalması ve işten ayrılma niyetinin artması gibi örgütsel ve bireysel birçok olumsuz sonuçları vardır. Karşı fikirlere duyarlı olma, işgörenlere anlayışl ve müsamahakâr davranma, örgütte güven ortamı oluşturma, işgörenlere sorumluluk ve inisiyatif vererek alınan kararlara dâhil etme bu sorunu önlemenin yolları arasındadır. Yine katılımın örgüte sunacă̆ı yararların farkında olarak katılımcı bir örgüt ortamı inşa etme, ortak akılla karar alma, sinerji oluşturmak için kubaşık bir çalışma ortamı sunma, demokratik, insani ve kolektif bir liderlik tarzı benimseme, güç kullanma yerine sorumluluk verme, kontrolden uzaklaşarak stratejiye odaklanma, işgörenleri esnek ve özerk bir şekilde istihdam etme, girişimcilik, yaratıcılık ve yenilikleri teşvik etme, sağlıklı bir iletişim imkânı oluşturma, bilgiyi ulaşılabilir kılma, amaç birliği oluşturarak ortak bir hedef gösterme, kişisel menfaat yerine sorumluluğu dizayn ederek güven ortamın kurma, katılımsızhğ̆ ortadan kaldıracak diğer çözüm stratejileri arasında sayılabilir.

\section{Abstract}

In this study, it is tried to present a conceptual framework about the problem of non-participation management that arises in organizations. In order to achieve this goal, what the non-participation management problem is, its types, causes, consequences and what needs to be done to prevent it are mentioned. According to the results of the study, the most important aspects of non-participatory management are not involving employees in management, not delegating authority, not empowering personnel, and organizational non-democracy. The problem of unattended management has many organizational and personal negative consequences such as low motivation, burnout, deterioration of the work environment, loss of efficiency and performance, decreased administrative efficiency, increased resistance to change, decreased organizational commitment and increased intention to quit. Being sensitive to opposing ideas, treating employees with understanding and tolerance, creating an atmosphere of trust in the organization, including employees in decisions taken by giving responsibility and initiative are among the ways to prevent this problem. Again, being aware of the benefits of participation to the organization, building a participatory organizational environment, making decisions with common wisdom, offering a flat working environment to create synergy, adopting a democratic, humane and collective leadership style, giving responsibility instead of using force, focusing on strategy by moving away from control, employees Employment in a flexible and autonomous manner, entrepreneurship, encouragement of entrepreneurship and innovation, creating a healthy communication opportunity, making information accessible, showing a common goal by creating a unity of purpose, establishing an atmosphere of trust by designing responsibility instead of personal benefit, and other solution strategies to eliminate non-participation can be counted between.

\section{Giriş}

Günümüzün değişken, dinamik ve rekabetçi koşulları, örgütlerin en stratejik öğesi olan insan kaynağının daha etkin yönetimini zorunlu kılmaktadır. Bu sağlanamaz ise örgütler bozulmaya, 
aksamaya (entropiye) maruz kalacak ve başarısızlığa sürüklenecektir. Entropinin ve başarısızlığın önüne geçebilmenin en temel yolu; insan kaynağının verimli, etkin ve koordineli bir şekilde yönlendirilmesidir. Katılım, bu yönlendirme sürecinin sağlıklı bir şekilde işlemesinde gerekli olan araçlardan biridir. Yönetimin en temel ilkeleri arasında yer alan/alması gereken demokratik yönetimin bir yansıması olan katılımcı yönetim, işgörenlerin fikirlerinin önemsenmesi, kararlara dâhil edilmesi, yetkinin paylaşılması ve alt kademelere doğru yayılması şeklinde kendini gösterir.

Katılımın tam tersi olan katılımsızlığın ise yetkiyi paylaşmamak, kendi başına karar almak, istişare ve kolektif akla başvurmamak, inisiyatif ve sorumluluk vermemek gibi tezahürleri vardır. $\mathrm{Bu}$ yönü ile katılımsız yönetim; örgütlerin yönetime katılma, yetki devri, personeli güçlendirme ve demokratik yönetim mekanizmalarını çalıştırmaması olarak ele alınabilir. Motivasyon düşüklüğü, örgütsel bağlılığın azalması, iş tatminsizliği, yalnızlaşma, performans ve verim düşüklüğü gibi vahim ve hayati sonuçları olan katılımsız yönetim anlayışı, örgütlerde yaşanan en önemli aksaklıklar (sorunlar) içerisindedir. İşgörenlerin alınan kararlara katılamaması, yetki devrinden mahrum kalmaları, yaptıkları işlerle ilgili inisiyatif ve sorumluluk alamamaları ve özgür, demokratik bir örgüt ortamından yoksun olmaları, örgütlerde katılımsız yönetimin en önemli veçheleridir.

\section{Katılımsız Yönetimin Veçheleri}

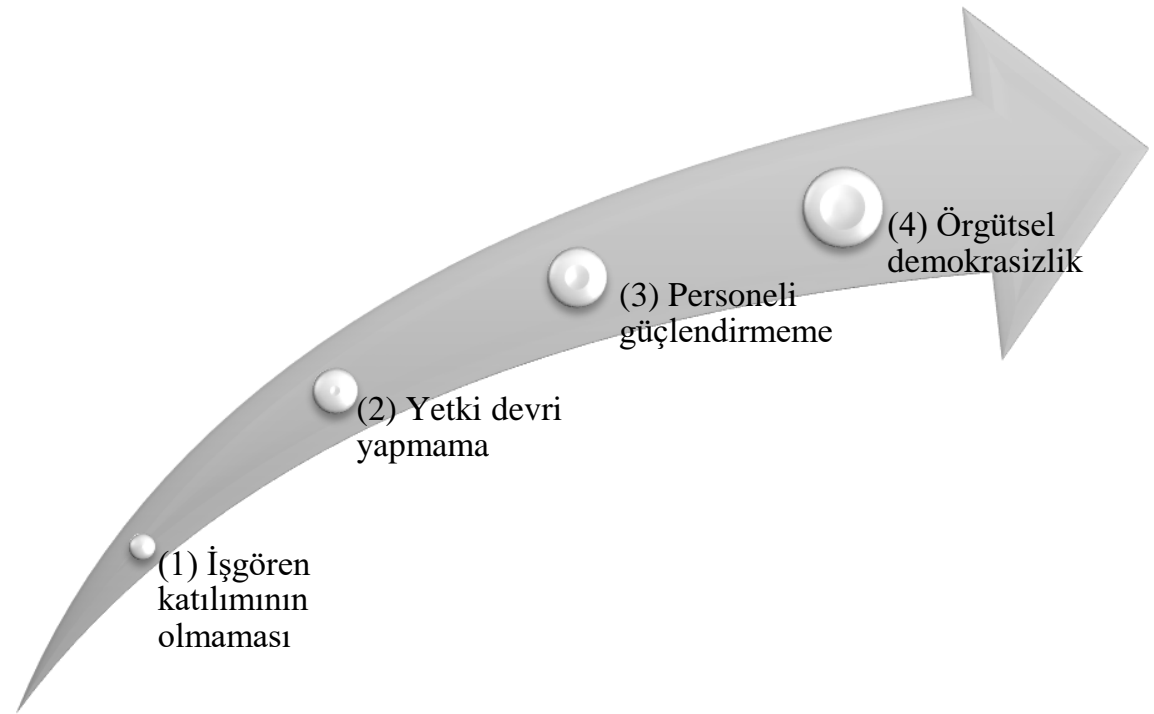

Şekil 1. Katılımsız Yönetimin Veçheleri

Şekil-1'de görüldüğü üzere örgütlerde katılımsız yönetim; (1) işgörenlerin yönetime katılamaması, (2) yetki devrinin yapılmaması, (3) personelin güçlendirilmemesi ve (4) örgütsel demokrasinin çalıştırılmaması şeklinde kendini göstermektedir. Dolayısıyla katılımsız yönetimin veçhelerini, bu yönetim uygulamalarının işlememesi ya da işlerlik kazanmamasında aramak gerekir.

\subsection{Yönetime Katılımın (Katılımcı Yönetim, İşgören Katılımı/İştirakinin) Olmaması}

Örgütlerin en önemli kaynağı olan insan unsurunu etkin bir biçimde organize etmenin en üstün formülü, katılımdır (Özel, 2016: 10). İşgörenlerin işlerin nasıl düzenlenmesi, yerine getirilmesi ve sürdürülmesine ilişkin kararları etkileme derecesini (McShane ve Von Glinow, 2016: 127) ifade eden yönetime katılım, karar verme ve uygulama yetkisinin uygulayıcılara doğru genişletilmesiyle işlerlik kazanır (Eren, 2016: 473). Az da olsa her örgütte katılım vardır. Burada önemli olan, katılımın derecesinin ne kadar olduğudur. Bazı örgütlerde, neredeyse bütün işgörenler alınan kararlara yüksek düzeyde katılım sağlarken; bazılarında, işgörenlerin bir kısmı daha kısıtlı bir düzeyde katılım göstermektedir.

Katılımsız yönetim, örgütün işgörenlerden vazifelerini icra etmeleri için üstün bir gayret sarf etmelerini talep etmelerine karşın yaptıkları işler ve karşılaştıkları sorunlarla ilgili fikir, görüş ve karar bağlamında bir katkıyı kabul etmemelerinden ortaya çıkar. Yine katılımsız yönetim, 
yöneticilerin işlerin yapılmasından asıl sorumlu olan kişiler olan astların, fikir ve kararlarını göz ardı etmeleri, önemsememeleri ve onları verilen emirleri yerine getiren bir robot gibi algılamaları sonucunda meydana gelmektedir. Oysa işlerin yapılmasından sorumlu olan astlar, bu işlerle ilgili bilgi, deneyim ve pratikliğe sahip kişilerdir.

\subsection{Yetki Devri (Yetki Göçerme, Delegasyon) Yapmama}

Yetki, bir yöneticinin belli bir süre ve şartlarda kullandığ1 emir verme hakk1 (Efil, 2005: 26) demektir. Yönetime katılımın bir ileri aşaması olan yetki devri ise yöneticinin sahip olduğu bu emir verme hakkını (yetkiyi), yine belli süre ve şartlarda astına devretmesidir (Koçel, 2011: 222). Yetki devri, bu yönü ile yönetim sürecinde yer alan örgütleme adımının en temel ilkeleri arasındadır. Çünkü bir yöneticinin tek başına bütün işlerin üstesinden gelmesi söz konusu değildir. Hele ki örgütün hacmi büyüdükçe bu durum daha da karmaşık bir hal alır. Böyle durumlarda yöneticilerin sahip oldukları yetkilerin bazılarını, astlarına devretmesi gerekecektir.

Bir örgütün başarısı, amaçlarına ne derece ulaştığı ile doğru orantılıdır. Amaçlara ulaşmak için ise insana ihtiyaç vardır. Zaten yönetim, en basit tanımı ile amaçlara ulaşmak için başkaları aracılığı ile iş yapma sanatıdır (Koçel, 2011: 58-59). O zaman örgütün başarısı için başkalarıyla beraber çalışmak ve onlarla işbirliği yapmak gerekmektedir. Hatta bu işbirliği ve birlikteliğin uyumlu, koordineli ve etkin bir şekilde yürütülmesi gerekmektedir. İşte bu birlikteliğin yolu, yetki devrinin kullanımından geçmektedir. Ĕger yöneticiler yetki devrini yerine getirmez ise yönetimin işlevlerinin yerine getirilmesinde aksaklıklar meydana gelecektir. Yönetim sürecinde yaşanacak bir sorun, örgütün girdilerini ve kaynaklarını verimli kullanımına engel olacağı için örgütün performansını da etkileyecektir.

Yetki devrini, belli görevlerin gerçekleştirilmesi için yetkinin bir yöneticiden diğerine aktarılması olarak tarif eden Eren (2016: 275), yetki devrinin üç yönünden bahseder: (1) Bir yöneticinin astlara görevler vermesi, (2) anlaşmalar yapmak, kaynakları kullanmak ve görevleri yerine getirmek için serbestlik tanıması ve (3) astın görevlerini yaparken yöneticilere karşı sorumluluk taşıması. Örgütlerde, astlara görev ve sorumluluk verilmesine karşın bunlara denk gelecek bir şekilde yetki verilmemektedir. Buna mukabil hiçbir astın, yürütme yetkisi verilmeyen görev ve sorumluklardan ve bunların sonuçlarından sorumlu tutulmaması gerekmektedir. Astlara, yaptıkları vazifelerin üstesinden gelebilmesi için sorumluluklarına denk bir şekilde yetki de verilmelidir. Bunun yanında, örgütlerde, işlerin yürütülmesinde gerekli serbestliğin tanınmaması konusunda da aksaklıklar yaşanmaktadır. Yöneticiler, her türlü görevleri astlarına aktarmalarına karşın onlara, görevleri yerine getirirken istedikleri kararları alma ve emirleri verme serbestliği tanımamaktadırlar.

\subsection{Personeli Güçlendirmeme (Yetkinlendirmeme)}

İşörenlerin sınırlandırılmasını ortadan kaldıran, kendi kararlarını vermelerini sağlayarak esnek davranmalarına imkân veren (Gümüştekin, 2015: 133) ve yetki devrinin bir sonraki adımını işaret eden personel güçlendirme, işin asıl uygulayıcıları ve sorumluları olan işgörenlere, yaptıkları işlerle ilgili karar verme yetkisinin de verilmesi, sorumluluk yanında inisiyatif almalarının da teşvik edilmesi demektir. O zaman personeli güçlendirmeme, işgörenlere, özgürleşerek gelişimleri için fırsat (Litreel, 2007: 35), yeteneklerinin gelişimi için olanak (Choi, 2006: 3), karar verme, onaylama ve sorumluluğunu üstlenme yetkisi (Gandz, 1990: 74; Jones, 2004: 154), güç ve otoritelerini arttırma imkânının (Klagge, 1998: 548) verilmemesidir.

Aslında personel güçlendirme, yetki devrinden farklı olarak, işgörenlere yetki devri yapılmasını değil işgörenlerin yetkin duruma gelmelerini ifade etmektedir (Gümüştekin, 2015: 139). Bu anlamda personel güçlendirmeme; işgörenlerin, karar verme ve yaptıkları işleri etkileyebilmeye dair inançlarının (etki), işleri yapabilmek için gerekli yetenek ve kapasiteleri olduğuna dair kanaatlerinin (yeterlilik), bakış açıları, inanç ve değerleri ile işin gerektirdiği rol arasındaki uyumun (anlamlılık) ve seçim hakkı olup olmadığına dair bireysel algılarının (özerklik) olmaması durumudur (Sigler ve Pearson, 2000: 29; Spreitzer, 1995; 1443; Gümüştekin, 2015: 141). 


\section{Tablo 1. Bir Hikâye: Fabrika Müdürü}

Büyük bir işletmenin yönetim kurulu üyeleri kâr ve zarar hesaplarını incelerken fabrika müdürünün aylığına takılmışlar ve bu ücretin yüksek olduğunu düşünmüşler. İçlerinden iki kişi seçerek fabrika müdürünün neler yaptığını görmelerini ve ondan sonra bu konuda karar verilmesini kabul etmişler.

İki kişilik heyet bir sabah sessizce fabrikaya gitmiş ve fabrika müdürünün odasına girmiş. Gördükleri manzara şu olmuş: Fabrika müdürü elinde kahve fincanı, ağzında purosu, etrafa halka dumanlar yaymakla meşgul. Masanın üstünde ne bir dosya, ne bir kâğıt, hiçbir şey yok. Bir müddet kendisi ile oradan buradan konuşan heyet üyeleri, bu müddet zarfında müdürün hiç bir işle meşgul olmadığını ve yalnız birkaç basit telefon konuşması yaptığını görmüşler.

Heyet aldığı intibadan memnun, idare meclisine “Fabrika müdürü denilen zatın yanında bulundukları üç kusur saat zarfında hemen hemen hiçbir şeyle meşgul olmadığını ve bu bakımdan böyle basit bir iş için verilen yıllık 100.000 dolardan en aşağı üçte ikisi nispetinde bir tasarruf sağlanabileceğini" söylemiş. Tabii fabrika müdürü bu indirmeye razı olmamış, işten ayrılmış. Yeni maaşla çalışmayı kabul eden birçok istekli arasında bir zat, yeni fabrika müdürü tayin edilmiş. Üç aydan sonra idare meclisine gelen imalat istatistiklerinde az, fakat dikkati çekecek kadar bir düşme başlamış. "Fabrika müdürü yenidir, tabii bu kadar acemilik olur" demişler. Altıncı ayın sonunda üretim ve kâr istatistik eğrisi bir hayli düşmüş. Hatalı üretim miktarı ise artmış.

Eski heyet azaları, yeni fabrika müdürünü odasında ziyaret etmişler. Adamcağız kan ter içinde bir elinde telefon, öteki eli evrak imzalamakla meşgul, başıyla gelenlere oturmalarını işaret etmiş. Gelen giden o kadar çok ki, adamla doğru dürüst konuşmaya bile imkân olmamış. Fakat heyetin kanaati şu olmuş: "Böyle canla başla çalışan bir adam başta olduğu müddetçe işlerin düzelmemesi için hiçbir sebep yoktur, biraz daha bekleyelim."

Sene sonu gelmiş, her zaman kâr eden fabrikanın bilançosu zararla kapanınca idare meclisi azaları birbirlerine girmişler ve işi yeniden incelemeye başka bir heyeti memur etmişler. Yeni heyet müdürün odasına değil fabrikaya gitmiş ve iş başında bekleyen insanlar görmüş, sebebini sormuş. Aldıkları cevap şu: "Hususi bir döküme başlayacağız. Fabrika müdürü ben gelmeden başlamayın dedi, bizde bekliyoruz. Herhalde elektrik atölyesinden bir türlü ayrılmaya vakti olmadi."

O sırada gözleri, yaşlı bir ustabaşına ilişmiş. Adamı şöyle bir kenarı çekmişler ve fabrikanın eskiye nazaran daha fena çalışmasının sebeplerini sormuşlar. Yaşlı ustabaşı içini boşaltmak ihtiyacını uzun zamandır hissetmiş olacak ki, "Baylar" demiş: "Eski müdürümüz teferruatla uğraşmaz, ileriye ait planlar yapar, işi bize bırakır, biz de normal zamanlarda onu rahat bırakırdık. Ani, içinden çıkamayacağımız olağanüstü bir problemle karşılaştığımızda ancak o zaman ona başvururduk ve bilirdik ki o bizim bu sorunumuzu çözecek. O hakiki fabrika müdürü idi. Güler yüzlü idi. Purosunu içer, bizimle şakalaşır, fakat hepimiz için düşünürdü. Şimdiki müdür de çok dürüst, iyi niyet sahibi, hatta çok daha çalışkan bir adam. Fakat o hiçbirimize inanmıyor, her işin kendisi tarafından görülmesini istiyor. Yani o bizim yerimize ustabaşılık yapıyor. Tabii biz de amele çavuşu mertebesine düşüyoruz. Haydi, neyse buna da aldırmayalım ama fabrika müdürlügüü boş kalıyor. Elinde purosu ileriyi görmeye çalışan, tedbir alan, düşünen adamın yerinde kimse yok."

Eski fabrika müdürünü tekrar oraya getirmek isteyen idare meclisi, bir senelik acı tecrübesinden sonra 100.000 yerine 150.000 dolarla onu ancak gelmeye razı etmiş.

Kaynak: Nüvit, O. (2019), İnsan Mühendisliği Hayat Karşısında İnsanın Kendisi ve Çevresi, İstanbul: Alfa Yayınları.

\section{4. Örgütsel Demokrasiyi Çalıştırmama (İşgörenleri Özgürleştirmeme)}

Günümüz bilgi toplumunda, hareket ve rekabet ön planda olduğundan böyle bir ortamda insan kaynağının özgür ve nazik bir şekilde yönlendirilmesi gerekmektedir (Özel, 2016: 36). Çünkü böyle bir ortamda yer alan insan kaynağı, muhakeme ve düşünme yeteneklerinin yanında (Eren, 2016: 474) bilgi gücüne de sahiptir ki, bu tür özelliklere sahip işgörenlerin kendi düşüncelerini serbest bir şekilde dile getirmek istemeleri ve özgür bir örgüt ortamı talep etmeleri, demokrasinin bir gereğidir. Dolayısıyla bilgi toplumunda örgütler, demokratik olmak zorundadır. Yani bu örgütlerde patronast ilişkisi, merkezi yönetim ve hiyerarşi olmaması gerekir. Bunun yerine adem-i merkeziyet, sıfır ve yatay hiyerarşi tesis edilmelidir. Çünkü işgörenler, özgür oldukları ölçüde örgüte faydalı olabileceklerdir. Ancak bunu başarabilen örgütler, yoğun rekabet ortamlarında yaşama imkânı bulabilir (Peters, 1992; Özel, 2016: 142).

\section{Katılımsız Yönetimin Nedenleri}

Katılımsız yönetimin en büyük nedeni, yöneticilerin yönetilenlere güvenmemesi ve değer vermemesidir. Ancak bunun yanında örgüt iklimi ve kültürü, yöneticilerin tarzı, yönetilenlerin tecrübe ve yetenek düzeyleri, dış çevre koşulları, iş koşulları gibi faktörler de katılım üzerinde etkilidir. Bunların yanında yönetilenlerin gerekli bilgi ve tecrübeye sahip olma dereceleri, durağan 
ya da dinamik çevre koşulları nedeniyle işlerin aciliyet derecesi, faaliyetler arası koordinasyon gerekliliği, yönetenlerin iş yoğunlukları ve ne kadar becerikli oldukları, yönetenlerin yönetim anlayışları, katılımın sağlayacağı yararlara verilen değer gibi faktörler de, örgütlerde katılımı etkileyen unsurlar arasindadir (Eren, 2016: 277).

Görüldüğü üzere katılımsız yönetimin kimi nedenleri, yönetenlerle ve yönetilenler ile ilgili iken; kimi nedenleri de, örgüt ve çevresi ile ilgilidir. Örgütlerde katılımsızlığın nedenlerini, Tablo 1'de daha ayrıntılı görmek mümkündür (Eren, 2009: 277; Eren, 2016: 277).

Tablo 2. Katılımsız Yönetimin Nedenleri

\begin{tabular}{|c|c|c|}
\hline $\begin{array}{c}\text { Yöneticilerden kaynaklanan } \\
\text { nedenler }\end{array}$ & $\begin{array}{c}\text { Yönetilenlerden kaynaklanan } \\
\text { nedenler }\end{array}$ & $\begin{array}{c}\text { Örgüt ve çevresinden kaynaklanan } \\
\text { nedenler }\end{array}$ \\
\hline $\begin{array}{l}\text { İşleri en iyi ben bilirim ve yaparım } \\
\text { düşüncesi. }\end{array}$ & $\begin{array}{l}\text { Bir meseleyi inceleme, araştırma ve } \\
\text { akıl yürütme yerine üstlerine sorma. }\end{array}$ & $\begin{array}{l}\text { Teşvik ve motivasyonun yetersiz } \\
\text { oluşu. }\end{array}$ \\
\hline $\begin{array}{l}\text { Plan, program ve stratejileri astlara } \\
\text { söylemekten kaçınma. }\end{array}$ & Eleştirilme korkusu. & Merkezi organizasyon yapısı. \\
\hline Astları yeterince tanımama. & $\begin{array}{l}\text { Gerekli bilgi, deneyim ve becerilerden } \\
\text { yoksun olma. }\end{array}$ & $\begin{array}{l}\text { Verilecek kararların örgüt için } \\
\text { taşıdığı stratejik önem. }\end{array}$ \\
\hline Astlara güvenmeme. & İş yükünün çok olması. & İşlerin hızlı yapılma zorunluluğu. \\
\hline Riske girmek istememe. & Özgüvensizlik. & $\begin{array}{l}\text { Denetim ve ikaz mekanizmalarının } \\
\text { olmaması. }\end{array}$ \\
\hline Gözden düşme korkusu. & Yetersizlik düşüncesi ve kayg1. & $\begin{array}{l}\text { Yetki ve sorumluluk sınırlarının } \\
\text { açık ve net olmaması. }\end{array}$ \\
\hline $\begin{array}{l}\text { Otorite ve gücünün sarsılacağ1 } \\
\text { korkusu. }\end{array}$ & Sorumluk almaktan kaçınma. & $\begin{array}{l}\text { Grup kararlarının kişisel } \\
\text { kararlardan daha maliyetli olması. }\end{array}$ \\
\hline Yönetim tarzı, işgörenlere bakış. & İş yükünün artacağını düşünme. & $\begin{array}{l}\text { İşletmenin küçük ve sahiplerinin az } \\
\text { olması. }\end{array}$ \\
\hline Astları rakip olarak görme. & $\begin{array}{l}\text { Üstlerini ve örgütünü sevmeme } \\
\text { nedeniyle destek vermek istememe. }\end{array}$ & $\begin{array}{l}\text { Ekonomik, sosyal, kültürel, } \\
\text { teknolojik, demografik ve politik } \\
\text { açılardan değişken çevre koşulları. }\end{array}$ \\
\hline Astları kiskanma. & Göz önünde olmak istememe. & \\
\hline $\begin{array}{l}\text { Alınacak kararları önceden planlama } \\
\text { nedeniyle işgören katılımına ihtiyaç } \\
\text { duymama. }\end{array}$ & $\begin{array}{l}\text { Amaç ve çıkarların, örgüt amaç ve } \\
\text { çıkarları ile çatışması. }\end{array}$ & \\
\hline
\end{tabular}

Kaynak: Eren, E., (2016) Yönetim ve Organizasyon: Çağdaş ve Küresel Yaklaşımlar, İstanbul: Beta Yayınları, s. 277; Eren, E., (2009), Yönetim ve Organizasyon: Çağdaş ve Küresel Yaklaşımlar, İstanbul: Beta Yayınları, s. 277.

Tablo 2'de belirtilenlerin yanı sıra amaçların belirlenmemesi, işgörenlerin işe dâhil edilmemesi, örgütsel adaletin sağlanamaması, işgörenlerin örgütte neler olduğunu bilmemeleri (örgütü anlayamamaları), işgörenlerin kendilerini geliştirme fırsatlarının olmaması, kaynak yetersizliği, çekici bir örgüt vizyonunun olmaması, katılımsız yönetimin nedenleri arasındadır (McShane ve Von Glinow, 2016: 88-89). İlaveten yöneticinin kişiliği ve yönetim anlayışı, katılımsız yönetime sebep olan faktörlerdendir. Bazı yöneticiler, yetkilerini devrettiklerinde, güç ve otoritelerini kaybedeceklerinden korkarlar. Bunun yanında astlara emir verip istediğini yaptırabilme erki ve vazgeçilmez adam olma/olduğu düşüncesi, bazı yöneticilerin egosunu tatmin etmekte ve bu duygudan vazgeçmek istemeyen yöneticiler, katılımdan kaçınmaktadır (Eren, 2016: 278). Katılımın önündeki engeller içerisinde kültürün yadsınamaz bir yeri vardır. Özellikle Türk kültüründe yöneticilerin tarzından kaynaklı yetkiyi elinde bulundurma ve kendini vazgeçilmez görme anlayışı, "Benden habersiz kuş uçmaz." şeklinde bir pratiğe dönüşebilmektedir.

Katılımsız yönetim, biraz da örgütün ve yöneticilerinin, işgörenlerden yapacakları görev ve işler, karşılaşacakları sorunlar ve çözüm yollarına dair bilgi sakındıkları ve astlarına karşı güvenlerinin az olması hasebiyle işleri kendileri yürütmek ve kontrol etmek istedikleri koşullarda gerçekleşir (McShane ve Von Glinow, 2016: 127; Eren, 2016: 278). Oysa sorunlar ve problemler tanımlansa ve işgörenlerden bireysel ya da toplu olarak sorunların ve problemlerin çözümlerine dair öneri ve görüşler alınsa ve güven düzeyi yüksek olsa, katılım daha yüksek seviyede olur. İşletmede, problem ve sorunlar işgörenlere açıklandığı ve onlara güvenildiği ölçüde, katılım artar.

Yöneticilerin denetim ve kontrollerinin azalacağını düşünmeleri, katılımın her ekonomik koşulda inandırıcı bulunmaması, katılım sonucu üyeler arasında sıkı bir bağlılık oluşacağı ve bunun 
sonucunda örgüte karşı işbirliği riskinin doğabileceği fikri, işgörenlerin ilgisiz konulara da burunlarını sokmak isteyecekleri ve sonuç olarak örgütün yanlış kararlar vererek zarar göreceği görüşü ve işverenlerin mülkiyet haklarını kaybedeceklerine dair inançları, katılımsız yönetimin nedenleri arasındadır (Eren, 2016: 482). Kolektif karar vermenin bireysel karar vermeye göre daha maliyetli olması, katılımsız yönetimin diğer bir önemli nedenidir (Eren, 2016: 483). Çünkü en basit hesapla fayda maliyet analizi yapıldığında, alınan kararın faydası (getirisi), maliyetinden fazla olmalıdır.

Zaman kısıtı, üretimin durması ya da yavaşlaması, değerlendirilme kaygısı, uyum ve grup baskısı gibi faktörler de katılımsız yönetime sebep olmaktadır (McShane ve Von Glinow, 2016: 127). İsgören katılımı ile verilen kararlar, bireysel verilen kararlara göre daha uzun zaman almaktadır. Çünkü bireysel kararlara nazaran katılımlı kararlar, organize, koordinasyon, ilişki ve iletişim kurmayı ve uyumu gerektirmektedir. Hatta işgören katılımı ne kadar genişlerse o kadar zamana ihtiyaç vardır. Zaman almasının yanında işgörenlerin, diğer çalışma arkadaşlarının kendilerini değerlendirdikleri kaygısıyla fikirlerini beyan etmemeleri, yani başkalarınca değerlendirildikleri kaygısını taşımaları, katılımsız yönetimi artıran bir diğer nedendir. İlave olarak işgörenlerin ait oldukları birim, grup ya da takımların güçlü normları, fikir birlikleri, bağlılık düzeyleri ve grup düşünceleri sonucu oluşan uyum baskısı, işgörenlerin katılımını sınırlandırmaktadır. Çünkü herhangi bir işgören, ait olduğu gruptan ayrı bir fikre ya da görüşe sahipse kendi görüşünü sorgulayacak, revize edecek, hatta dişlanma ve reddedilme korkusu ile bunu dile getirmekten çekinecektir.

Diğer taraftan örgütün büyüklüğü, örgütte mülkiyetin yaygınlığı, uzlaşma ve çatışma kültürü de katılımın belirleyicileri arasındadır. Örneğin, sahiplerinin az olduğu küçük örgütlere nazaran mülkiyetin yaygın olduğu büyük örgütlerde, yine ilişkilerin çatışma üzerine kurulu olduğu ABD, Fransa ve İtalya gibi ülkelerdeki örgütlere karşı uzlaşma üzerine kurulu olduğu Almanya ve İngiltere' deki örgütlerde, yönetime katılımın etkinlik olasılığı daha fazladır (Eren, 2016: 483). Mülkiyetin sınırlı olduğu küçük örgütlerde, örgüt sahiplerinin yönetim ve mülkiyeti kaybedecekleri korkusu da katılımı sinırlı düzeyde tutmaktadır.

\section{Katılımsız Yönetimin Sonuçları}

Katılımsız yönetim, örgütlerin en önemli sorunları arasında yer almaktadır. Yapılan bir araştırmaya göre, $\mathrm{ABD}^{\prime}$ de işgörenlerin sadece \%30'u yüksek düzeyde yönetime katılmaktadır. İşgörenlerin yaklaşık yarısı, az çok veya hiç, beşte biri ise düşük ya da aktif bir şekilde katılım göstermektedir. Aktif bir şekilde yönetime katılım sağlayamayan işgörenlerin sadece motivasyonları düşmemekte bunun yanında tükenmişlikleri de artmaktadır (Sabuncuoğlu ve Tüz, 2001). Bunların sonucunda, çalışma ortamını bozma ve diğer işgörenlerin motivasyonlarını da bozma davranışları göstermektedirler (McShane ve Von Glinow, 2016: 88-89). ABD ve Batı Avrupa ülkelerinin yanında ülkemizde de katılıma dair uygulamaların çok sınırlı kaldığı söylenebilir (Eren, 2016: 478).

Katılımsız yönetimin yönetenler, yönetilenler ve örgüt açısından olumsuz sonuçları vardır. Katılım olmadığında, öncelikle yöneticilerin üzerlerindeki tali, detay, rutin ve standart işler artacak, bu sebeple de yöneticiler bilgi ve zamanlarını iyi yönetemeyecekler ve daha önemli işlere fırsat bulamayacaklardır. Bunun yanında yöneticilerin karar verme süreçlerindeki verimlilikleri ve yönetsel etkinlikleri de azalacaktır (Şakar, 2013: 85; Eren, 2016: 278-279; Eren, 2016: 474). Sonuç olarak yöneticilerin verimliliği düşecektir.

Yönetilenler açından meseleye bakıldığında, katılımsız yönetim, yönetilenlerin karar alma becerilerinin gelişmesini engelleyecek, yeni bilgi ve tecrübe kazanma şansı bulmalarına imkân tanımayacak, amaç birliği oluşmayacak, alınan kararlara muhalefet etmelerine sebep olacak, değişime dirençleri artacak, motivasyon ve verimlilikleri düşecek, örgütsel bağlllıkları azalacak, işten ayrılma niyetleri artacak, kendilerini değersiz, moralsiz ve özgüvensiz hissedeceklerdir (Şakar, 2013: 85; Eren, 2016: 278; Eren, 2016: 479-480). Çünkü artık işgörenler, basit bir işgören olmak yerine yönetime dâhil olmayı arzulamakta, kendilerini ilgilendiren kararlara aktif olarak katılmak, 
düşüncelerini söylemek ve danışılmak istemektedirler (Eren, 2016: 473). Bunun tersi bir durumun, önemli yönetsel ve psikolojik sorunlar doğuracağı aşikârdır.

Katılımsız yönetimin örgütlere yükleyeceği diğer sonuçlara bakıldığında, yönetenler ile yönetilenler arasında diyalog, işbirliği ve paylaşım ortamı oluşmayacağından örgütün ekonomik karar vermesi, yönetsel etkinliği ve verimliliği olumsuz etkilenecek, örgütler pratik ve tecrübe sahibi, vasıflı, iyi yetişmiş yöneticiler kazanamayacaktır (Eren, 2016: 474-475; Eren, 2016: 279). Aynı zamanda katılımın olmadığı örgütler, merkezi bir yapıda olacağından karar almak ve uygulamak oldukça güçleşecek, böylesi hantal yapıda olan bir örgüt, çevresel gelişmelere ayak uydurmakta zorlanacak ve esnekliğini kaybedecektir. Çünkü katılım, insanca bir eylemdir. İşgörenlerin hem iş tatminlerini hem de verimliliklerini arttırır. Sadece sermaye gücüyle ayakta kalabileceklerini düşünen ve katılıma önem vermeyen örgütlerin tıpkı benzerleri gibi tarihe karışacakları zaman yakındır (Özel, 2016: 100).

Bunların yanında katılımsız yönetim, örgütün gelişmesi ve ilerlemesine uygulanacak değişime dair direnci artırır ve işgörenlerin kararlara olan bağlılı̆̆ını olumsuz etkiler. Oysa karar verme sürecine katılan işgörenler, kendilerinin de katkı sağladığı kararların uygulanması için istekli davranırlar. Alınan kararlardan kaynaklanacak değişime karşı, daha az direnç gösterirler. Görüldüğü üzere katılım, örgütsel değişim anlamında önemli katkılar sunmaktadır (McShane ve Von Glinow, 2016: 128). Hiç şüphesiz ki katılım, örgütün isabetli kararlar alması ve başarılı olması için en önemli bileşenlerdendir. Bu sebeple en iyi kararlar vermek için en iyi bilgilere haiz işgörenleri bir araya getirerek karar verme sürecine dâhil etmek gerekir. Bu, işgörenlerin alınacak kararlara bağlılığını da arttıracaktır.

\section{Katılımsız Yönetimi Engellemenin Yolları}

Öncelikle yönetime katılmanın tarafları olan yöneten ve yönetilenlerin katılıma dair kararlı ve istekli olmaları, yönetsel faaliyetlere karşı bağlılık hissetmeleri, katılımın bilincinde olup değer vermeleri ve ciddiye almaları, kendilerinden ve yeteneklerinden emin olmaları, yönetenlerin karşı fikirlere duyarlı, müsamahakâr olmaları ve güvence vermeleri katılımı arttıracak unsurlardır (Eren, 2016: 482-483). Katılım yoluyla örgütte performans ve verimliliğin artması için işgörenlere sorumluluk, inisiyatif ve karar verme yetkisi verilerek işgörenlerin aktif olarak yönetime katılımları sağlanabilir (Gümüştekin, 2015: 148). Bunların yanında katılımı arttırmak ya da katılımsızlığ1 engellemek için bazı öneriler getirilmiştir.

\subsection{Katılımcı Bir Örgüt Kültürü Oluşturma}

Örgütlerin gelişip büyüyebilmeleri, daha etkin ve başarılı olabilmeleri için katılımı engelleyen örgüt kültüründen vazgeçmeleri gerekir. Katılımın benimsendiği bir örgüt kültürü, örgütteki her bireyin diğerlerinin farklı görüş ve bakış açılarına saygı duyduğu ve sadece ortak maksada odaklandığı yapıcı tartışma ikliminin oluşturulmasıyla kurulur. Bir örgütte katılımın varlığ için işbirliği ve paylaşımın olduğu, bilginin aktarıldığı, iletişimin açık ve net bir şekilde kurulduğu, işgörenlere sorumluluk ve inisiyatif verildiği ve kararlara dâhil edildiği bir örgüt kültürünün oluşturulması gerekmektedir.

\subsection{Katılımın Yararlarının Bilincinde Olma}

Katılımın karar verme kalitesini ve işgörenlerin örgütsel bağlılıklarını geliştirdiğine dair onlarca araştırma vardır. Yönetime katılan işgörenler, sorunları daha çabuk anlayacak ve tanımlayacak, bu da kararların daha isabetli olmasını sağlayacaktır (McShane ve Von Glinow, 2016: 127). Yöneticilerin işgörenlerin fikirlerini almaları, motive ve bilgi sahibi olmalarını sağlayacağından astları daha kolay yönlendirmelerini de temin edecektir (Eren, 2016: 466). Çünkü işin nasıl yapılacağı ile ilgili kararlara katılan işgörenler, o işi isteyerek yapacak, sorunun çözümüne dâhil olduğu için de sorumluluk hissedecektir. Bu durum, vazifesini severek, bilinçli bir şekilde yapan ve sorumluluk duygusuyla hareket eden astların, iyi birer işgören ve yönetici olarak yetişmelerine zemin hazırlayacaktır.

Yine katılım, işgörenlerin kendi görüş ve fikirlerine itibar edildiğini bilmelerini sağlayacağından işgörenlerin bağlılığı, motivasyonu, iş tatmini ve verimliliğini arttırmaktadır (Eren, 2016: 466; McShane ve Von Glinow, 2016: 128). Pek tabii bir durumdur ki, işgörenlerin kendilerini sadece başkalarının aldıkları kararları uygulayanlar olarak görmeleri, onları değersiz hissettirecektir. 
Bunun yerine karar verme sürecine dâhil olan işgörenler, kendilerini değerli bulacakları gibi özgüvenleri artacak ve alınan kararları kendi kararları gibi düşünerek sorumluluk hissedecektir. Bu sorumluluk da onların işlerine dört bir elle sarılmalarını sağlayarak örgüte olan bağlılıklarını yükseltecek, yaptıkları işle ilgili doyumlarını arttıracak ve daha etkin olmalarını temin edecektir.

\subsection{Kolektif Karar Alma}

Yadsınamaz bir gerçektir ki kolektif (takım olarak) karar alma, sorunları ve problemleri tanımlama, çözme, alternatifler üretme ve seçmede bireysel kararlardan daha etkilidir. Çünkü kolektif karar alma, karşıt fikirlerin ve bakış açılarının değerlendirilmesi ve daha değerli olan bilgilerin sınanması sayesinde, en iyi alternatifin seçilmesini sağlar. Zaten geliştirilen matematiksel bir teoremle de, grup ve takım kararı ile seçilen alternatifin, bireysel olarak seçilen alternatife nazaran daha isabetli olduğu ispatlanmıştır (McShane ve Von Glinow, 2016: 128; 147). Örgütler, başarılı olmak istiyorlar ise katılımı sağlamak için örgütsel yapılanmalarını takımlar şeklinde kurgulamalıdır. Bu, işgörenlerin kendilerini örgütün bir parçası gibi hissetmelerini sağlamakta ve bağlılıklarını arttırmaktadır (Gümüştekin, 2015: 153).

Katılımın sağlanması için beyin fırtınası, nominal grup, kalite çemberleri, ringişo gibi kolektif karar alma teknikleri kullanılabilir. Bu tekniklerden Japon yönetim anlayışlarının bir ürünü olan ringişo, katılımın nasıl olması gerektiği ile ilgili en güzel yollardan biridir. Ringişo tekniğinde, alt ve orta düzey yöneticilerden çıkan fikirler bütün işgören ve yöneticilerin görüşlerine sunularak tartışılır (Arıcıoğlu, 1995). Bu fikirler belli bir olgunluğa ulaşınca üst yönetime sunulur. Bu uygulamada amaç işgörenlerin aktif olarak fikirlere ve kararlara katılımını sağlamaktır.

Kolektif karar almak için kullanılabilecek diğer bir teknik ise beyin fırtınası tekniğidir. Bu teknik, katılanların birbirlerini eleştirmeden, özgürce görüş bildirmelerine imkân veren yüz yüze bir toplantıdır. Bu sayede mümkün olduğunca çok fikir üretilir, fikirler başka fikirleri yeşertir. Katılım için uygulanabilecek bir başka yöntem olan nominal grup tekniği de bir nevi beyin furtınası tekniğidir. Üç aşamalı ve yazılı olan bu teknikte, etkinliğe katılanlar, öncelikle bağımsız bir şekilde fikirlerini listeler, ikinci aşamada fikir ve önerilerini eleştiri olmadan diğerlerine aktarır, son aşamada bağımsızca sunulan fikirleri değerlendirerek bir öneri ortaya koyarlar.

Katılımın olmazsa olmazları arasında yer alan kolektif karar vermeyi geliştirmek için bazı öneriler de geliştirilmiştir (McShane ve Von Glinow, 2016: 128; 147);

- Eleştirel düşünme ve etkin tartışmayı cesaretlendir,

- Herkese fikirlerini sunmak için firsat tanı,

- Mümkün olduğu kadar herkesin tartışmaya katılmasını sağla,

- Herkesin özelliklerini açığa çıkar,

- Tartışmaları, birkaç makul seçenekle sınırlandır,

- Özellikle karmaşık konularda, son kararı vermek için en kıdemli kişiyi hakem olarak tayin et.

Kolektif karar alma örneği olarak örgütlere şöyle bir uygulama önerisi getirilebilir: Üretimden pazarlamaya, lojistikten insan kaynaklarına kadar tüm birimlerde sorunların çözümü, performans, etkinlik ve verimliliğin arttırılması, ürün-hizmetlerin geliştirilmesiyle ilgili fikir üretimi konusunda çalışanlar teşvik edilebilir. Yılsonunda düzenlenecek bir etkinlikle, en iyi fikirler ödüllendirilebilir.

\subsection{Kolektif Liderlik}

Liderliği, bireysel bir süreç olarak ele almak yerine kolektif bir süreç olarak yürütmek, örgütte katılımın sağlanması için daha doğru olacaktır. Çünkü bireysel liderliğin, kıskançlık ve sakınma ile korunmasına karşın; kolektif liderlik, paylaşım ve işbirliği ile gelişir. Bu sebeple bireysel liderlik tarzını benimseyen yöneticiler, paylaşımcı ve katılımcı olamazlar. Bunun yerine kolektif liderlik tarzının benimsemesi ise paylaşımı, işbirliğini, katılımı teşvik edecek ve geliştirecektir.

\subsection{Sinerji Oluşturma}

Takım üyeleri, çözüm yolları ve alternatiflere dair sahip oldukları fikirleri ve bilgileri, diğerleri ile paylaşarak bir sinerji oluştururlar (McShane ve Von Glinow, 2016: 127). Karar olma süreçlerinde ve uygulamada sağlanacak bir sinerji ortamı, işgörenlerin işbirliği ve takım halinde çalışmalarını sağlayacağından verim ve performanslarının, tek başlarına çalışıyor olmalarına göre, daha iyi olmasını sağlayacaktır. 


\subsection{Güç Kullanmak Yerine Sorumluluk Verme}

Bilginin örgütleri ve toplumu kökten dönüştürdüğü bir zamanda, örgütlerde mevki, otorite ve gücün yerine karşılıklı anlayış ve sorumluluğa dayalı bir örgütsel davranış hâkim olacaktır (Drucker, 1995: 149). Yetki devri bile örgütün üst basamaklarında yer alan gücün aşağıya doğru aktarımından başka bir şey değildir. İşletmenin başarısı ve devamlılığı için yetki devri, yani gücün aşağıya doğru aktarımı yerine sorumluluğun aktarımı daha doğru bir tercih olacaktır. Bu ise katılım ve yetki devrinin yanında personel güçlendirme ve işgöreni özgürleştirme ile mümkündür.

\subsection{Kontrolden Uzaklaşıp Stratejiye Odaklanma}

Özellikle üst düzey yöneticiler, her şeyi kontrol etmektense stratejiler üzerine odaklanmalı ve gerisini alt düzey yöneticilere bırakmalıdır (Drucker, 1995; Özel, 2016: 147). Zamanla işgörenleri kumanda ve kontrol etme felsefesinden uzaklaşarak çalışanların inisiyatif kullanmalarını teşvik eden ve öğrenme ve yenilik anlayışlı olmalarını sağlamayan bir bakış açısı, daha doğru bir yaklaşım haline gelmiştir. Ancak bu sayede yöneticiler daha mühim işlere odaklanabilecektir. Çünkü rutin ve standart işleri kontrol etmekten vazgeçip misyon, vizyon ve amaç belirlemek gibi daha uzun soluklu ve stratejik işlerle uğraşmak ancak katılım ile mümkündür. Bir yöneticinin stratejiye odaklanmasının yolu, kendisine vakit kaybettiren ve enerjisini tüketecek vazifeleri üzerinden atarak astlarına devretmesinden ve işgören katılımından geçmektedir.

\subsection{Esnek ve Özerk İşgörenler}

Sürekli rekabetçiliğin ancak bir örgütün ayakta kalmasını sağladığı, işlerin karmaşık ve değişimin çok hızlı olduğu bir çağda, sürekliliği sağlamanın formülü, esnek ve bağımsız iş görenlerdir. Esneklik ve özerklik, örgütte yaratıcılık ve yeniliğin ortaya çıkmasında en önemli etkenlerdendir. Katılımın varlığından bahsedebilmesi için işgörenlerin belli sınırlar içinde kalmalarına sebep olan uygulamalardan kurtularak işin yapılması ve karar verilmesinde özerkliğin sağlanması gerekmektedir (Gümüştekin, 2015: 154). İşgörenlerin, işin üzerinde kontrol ve yaptırım gücü arttığı sürece yaratıcılıkları artacaktır. İşgörenlerin katılımı ise iş ortamlarında bağımsız ve esnek olabilmelerine bağlıdır (Cacioppe, 1998).

\section{9. İç Girişimcilik ve Yaratıcılığı Teşvik Etme}

İşörenler, yaptıkları işleri en iyi bilen kişiler olmaları sebebiyle katılımın sağlanmasının bir formülü de yaratıcılıklarının ve girişimciliklerinin teşvik edilmesidir. İşgörenler, yaptıkları işlerle ilgili kontrolün kendilerinde olduğunu düşündüğ̈̈ sürece, yaratıcılık ve girişimcilikleri artacak, yaptıkları işler ile ilgili yeni yollar, alternatif formüller, yaratıcı ve yenilikçi fikirler üretecek, deneyecek ve önereceklerdir. Dolayısıyla iç girişimciliği ve yaratıcılığı teşvik etmek, katılımı arttıracak en önemli etkenlerdendir.

\subsection{Amaç Birliği Oluşturma}

İşgörenlerin, örgütün nereye, nasıl ulaşacağına dair ve örgütün faaliyetleri hakkında bilgi sahibi olması (Gümüştekin, 2015: 150), fikir ve görüşlerinin alınarak değerlendirilmesi, amaç birliğinin oluşmasını sağlayacaktır. Bunu sağlamanın yolu ise katılımdan geçmektedir. Vizyon, misyon, amaç ve hedefler oluştururken ya da plan, politika ve programları tayin ederken, ortak akıl ile hareket etmek, bilgiyi paylaşmak ve amaç birliğinin oluşturulmasına gayret etmek, işgörenlerin sorumluluk almalarını ve katılımlarını teşvik edecek ve cesaretlendirecektir.

\subsection{1. İletişimi İyileştirme ve Bilgiyi Ulaşılabilir Kılma}

İletişimin ve bilginin ulaşılabilir, şeffaf, açık ve net olması, katılımın başarısı için olmazsa olmazlar arasındadır. İşletmedeki olaylar ve gelişmelerden bihaber, örgütün program, plan, hedef, amaç, misyon ve vizyonunu bilmeyen bir işgörenin, katılımcı olması söz konusu değildir. Böyle bir durumda işgören, kendisini etkisiz hissedecektir (Brazier, 2005). Astların, örgüt amaçlarından haberdar olması, haberleşme kanallarının iş görenlerin etkili olabileceği şekilde tasarlanması, astların fikirlerini dile getirebilecekleri yazılı ve sözlü imkânlarının olması, katılımı teşvik edecektir (Eren, 2016: 483). İşletmede hiyerarşinin kendini hissettirdiği dikey iletişim yerine yatay iletişimin tercih edilmesi, işbirliği ve takım çalışmasını desteklemektedir (Emet, 2006). Örgütlerde iletişimin iyileştirilmesi adına şu adımlar takip edilebilir (Gibson vd., 1979: 418);

- Geri besleme mekanizmasinı aktif kullanma,

- Mesaj ve haber akışını iyi yönetme, 
- Mesajı alacak kişiler açısından empati yapma,

- Mesaj1 tekrar etme,

- Kullanılan dili mümkün olduğu kadar sadeleştirme ve

- İletişim kanallarını çeşitlendirme.

\subsection{Müsamaha ve Güven}

Korku, çekinme ve kuşku olmadan birine inanmak ve itimat etmek (güvenmek), katılımmn olmazsa olmazları arasındadır. Bir yöneticinin astlarına güvenmeden onlara söz hakkı vermesi, fikirlerini önemsemesi, alacağı kararlara dâhil etmesi, yetkilerini devretmesi, sorumluluk ve inisiyatif vermesi ve onları özgür bırakması söz konusu olamaz. Bu anlamda düşünüldügüñnde, katılımsız yönetimi engellemenin yollarından biri işgörenlere güvenmektir. Katılım için güvenin yanında işgörenlere hoşgörüyle davranmak, bazı davranışlarını görmezlikten gelmek ve tolerans göstermek de gerekir.

Katılım için üstler ve astlar arasında güven ortamının oluşturulması önemlidir. Çünkü katılım algısında güven etkilidir. İşgören, ast ve üstler arasında güvenin olması, işbirliğini arttıracak, ortak amaçlara göre hareket edilmesini sağlayacak ve örgütün performans ve verimliliğini arttıracaktır (Gümüştekin, 2015: 151).

\subsection{Menfaat Yerine Sorumluluğu Koyma}

Sorumluluk (vazife) ile menfaat, her insani davranış tarzının iki ayrı motivasyon gücünü oluşturmaktadır (İzzetbegoviç, 2013: 159). Yöneticilerin, kişisel çıkar ve menfaat üzerine kurulu bir davranış tarzı yerine sorumluluğa dayalı bir davranış tarzını benimsemeleri ve bunu tabana doğru yaymaları örgütte katılımın yeşermesi ve işlerlik kazanması için gerek şartlardandır. Sorumluluk sahibi olmak, ahlaki temelleri olan bir erdemdir. Yöneticilerin sorumluluk sahibi olması demek, kıskançlık ve kişisel çıkarlarını bir kenara iterek ellerinde bulundurdukları otorite ve güç gibi imkânları, örgütün menfaati doğrultusunda kullanmaları demektir. Çünkü sorumluluk sahibi olmak hiçbir zaman menfaatçi bir davranış değildir.

\subsection{Yetki Yerine Kazanılmış Yetki Kullanma}

Günümüzde yönetme gücü, sermaye ya da yetki sahipliği yerine kişisel bilgi ve özelliklerden beslenmekte ve ancak böyle olunca işlerlik kazanmaktadır (Eren, 2016: 473). Yoğun rekabet koşullarında insan kaynağını yönlendirmede, hiyerarşi ve yetki gücünün yerini örgütlerin organizasyon yapılarının hiyerarşik olmaktan uzaklaşması demek olan sıfır hiyerarşi ya da yatay hiyerarşi anlayışları almıştır. Hiyerarşinin sıfır ya da yatay olması, yönetenlerin sahip oldukları emir ve karar verme haklarını yukarıdan aşağıya doğru kaydırmaları ile olacaktır. Sıfır ya da yatay hiyerarşi durumunda, şu soru akla gelebilir: Yönetenler, yönetilenler üzerinde nasıl bir yaptırım gücü bulacak ve onları nasıl etkileyip yönlendirecekler? Hiyerarşi (otorite) gücü, yok olacağına ya da azalacağına göre bunu sağlamanın yolu; yöneticilerin bilgi, beceri, tecrübe, uzmanlık, ikna, karizma, liderlik, işbirliği, paylaşma ve katılımcı olma gücüne (kazanılmış otorite) bağlı olacaktır. Demek ki katılımsız yönetimi etkilemenin en önemli yollarından birisi; yetki yerine, kazanılmış yetkinin kullanımıdır.

4.15. Otokratik Yönetim Tarzı Yerine Demokratik (Katılımcı), İşi (Üretimi) Önceleyen Yönetim Tarzı Yerine Kişilerarası İlişkileri Önceleyen Yönetim Tarzının Benimsenmesi

Katılımın bir diğer belirleyicisi, yöneticilerin davranış tarzlarıdır. Burada, katılımın belirleyicileri; yöneticilerin astlara duydukları güven, astların özerklik algısı ve yöneticilerin katılıma dair astlarla kurduğu ilişkilerdir. Bu konuda yapılıış çokça araştırma vardır. Lewin ve diğerleri (1939), Argyris (1957), Likert (1961), Blace ve Mauton (1964)' un yaptığ1 yönetici davranışları araştırmaları göstermektedir ki, otokratik yönetim yerine, demokratik ve katılımcı yönetim tarzı; işi ve üretimi önceleyen yönetim tarzı yerine, kişilerarası ilişkileri önceleyen yönetim tarzı, örgütler için daha başarılıdır.

Yöneticilerin bencil, astlarını dikkate almayan, onlara güvenmeyen, onların fikir ve görüşlerini dikkate almayan, baskıcı bir tarz (otokratik) benimsemeleri durumunda, işgörenler için psikolojik açıdan tatminsizlikler yaşanacaktır. Bu ise işgörenlerin verimini, performansını, mesleki ve örgütsel bağlılığını, motivasyonunu azaltacak bir etkendir. Otokratik yönetim tarzı, yaratıcılığı da 
önlemektedir. Çünkü fikir ve görüşlerini dile getiremeyen işgörenlerin, zamanla susma alışkanlığ1 oluşacak ve yaratıcılıkları körelecektir.

Oysa demokratik ve katılımcı yönetim tarzında yöneticiler, astlarını dikkate alır, onlara değer verir ve güvenir, onların fikir ve görüşlerini önemser ve daha serbest hissetmelerini sağlar. Bu anlayış, yöneticilerin ve örgütün daha iyi karar almalarını sağladığı gibi işgörenlerin motivasyonlarını arttırır ve psikolojik bakımdan tatmin duygusu yaşamalarını sağlar. Doğal olarak bu durum, işgörenlerin performans ve verimliliği arttırarak mesleki ve örgütsel bağlılı̆̆ını da olumlu etkileyecektir.

\section{Sonuç ve Değerlendirme}

Örgütlerde, yönetime katılma, yetki devri, personeli güçlendirme, işgöreni özgürleştirme ve demokratik yönetim uygulamalarının kullanılmaması şeklinde ele alınan katılımsız yönetim hastalığı, yönetenler ve yönetilenlerden kaynaklı olabileceği gibi örgütsel ve çevre kaynaklı da olabilmektedir. Katılımsız yönetim hastalığının motivasyon düşüklüğü, tükenmişlik, çalışma ortamının bozulması, verim ve performans kaybı, yönetsel etkinliğin azalması, değişime direncin artması, örgütsel bağlılığın azalması ve işten ayrılma niyetinin artması gibi örgütsel ve kişisel birçok olumsuz sonuçları vardır.

Karşı fikirlere duyarlı olma, işgörenlere anlayışlı ve müsamahakâr davranma, örgütte güven ortamı oluşturma, işgörenlere sorumluluk ve inisiyatif vererek alınan kararlara dahil etme bu hastalığı önlemenin yolları arasındadır. Yine katılımın örgüte sunacağı yararların farkında olarak katılımcı bir örgüt ortamı inşa etme, ortak akılla karar alma, sinerji oluşturmak için kubaşık bir çalışma ortamı sunma, demokratik, insani ve kolektif bir liderlik tarzı benimseme, güç kullanma yerine sorumluluk verme, kontrolden uzaklaşarak stratejiye odaklanma, işgörenleri esnek ve özerk bir şekilde istihdam etme, girişimcilik, yaratıcılık ve yenilikleri teşvik etme, sağlıklı bir iletişim imkânı oluşturma, bilgiyi ulaşılabilir kılma, amaç birliği oluşturarak ortak bir hedef gösterme, kişisel menfaat yerine sorumluluğu dizayn ederek güven ortamını kurma, katılımsızlığı ortadan kaldıracak diğer çözüm stratejileri arasında sayılabilir.

Tüm bunların yanında katılımsız yönetim anlayışını ortadan kaldırmak için işgörenlere plan yerine seçenekler sunmak da bir çözüm yolu olabilir. Yapılacak işler ile ilgili planlar yapıp işgörenlerden bunların gerçekleştirilmesini istemek yerine, işgörenleri de işin içine katarak onlara yapılacak işler ile ilgili seçenekler sunarak bunlardan istediğini tercih imkânı vermek, onların daha yararlı hissetmelerini sağlayacaktır. Bunun yanında işgörenleri yetkilendirmek, onların gelişimlerini teşvik edici çalışmalar yapmak ve yaşam kalitelerini arttırmak da katılımsız yönetimi ortadan kaldırma stratejileri arasında sayılabilir. Yine işgörenleri sosyal sorumluluk projelerine yönlendirmek, özveri, fedakârlık, gönüllü katılım davranışlarını teşvik etmek ve ödüllendirmek, katılımı teşvik edecek yollardandir.

Kooptasyon da katılımsız yönetim anlayışının çözümü için alternatifler arasında sayılabilir. Kooptasyon, örgütte herhangi bir meseleye muhalif olan işgörenleri, o meselenin çözümü için uğraşan kişiler olarak değiştirmeyi ifade etmektedir. Böyle yapılırsa, herhangi bir konuya karşı muhalif bir pozisyonda olan işgören, meselenin dışında ve meseleye karşı bir rol oynamak yerine, meselenin çözümüne ortak edilerek ortadan kaldırılması için çabalayan bir işgören rolüne bürünecektir. Son olarak örgütlerin kontrolden uzaklaşarak işgörenlere öz yönetim anlayışını aşılaması, işgörenlerin kendi kendilerini denetleyebilecekleri doğal bir denetim ortamı oluşturmaları ve klan denetim anlayışını benimsemeleri, katılımsız yönetimi ortadan kaldıracak yollar olarak önerilmektedir.

Görüldüğü üzere katılımsız yönetim, örgütler için hayati sonuçları olan yönetimsel sorunlar içerisinde yer almaktadır. Ancak bu hastalığın varlığı kabul edilir, ne olduğu bilinir, kaynakları belirlenir, sonuçlarına vakıf olunur ve çözüm yolları için arayışa girişilir ise üstesinden gelinemeyecek bir yönetimsel problem değildir. Bu çalışmada, katılımsız yönetim hastalığının ne olduğu, hangi türlerinin olduğu, nedenlerinin neler olduğu, hangi sonuçları doğurduğu ve önlenmesi için neler yapılması gerektiği konularına değinilerek, söz konusu sorun ile ilgili bir çerçeve sunulmaya çalışılmıştır. Böylece sadece katılımsız yönetim sorunu teşhis edilmemiş, çözüm 
yollarına da değinilmeye çalışılmıştır. Konunun daha iyi anlaşılması ve bir çıktı sunulması adına oluşturulan Şekil 2'deki kavramsal harita ile katılımsız yönetim hastalığı özetlenmeye çalışılmıştır.

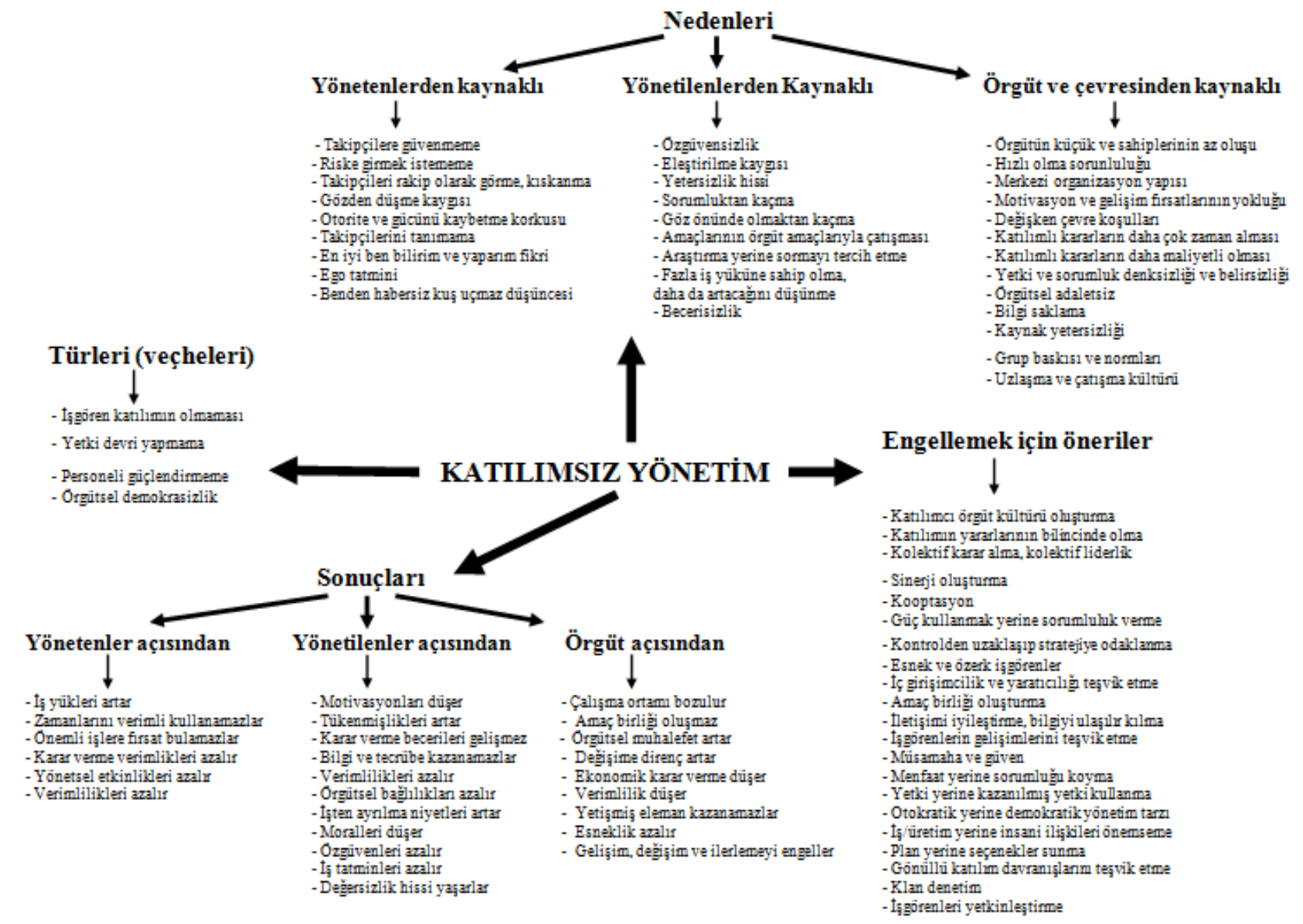

Şekil 2. Katılımsız Yönetim Sorunu

\section{Kaynakça}

Argyris, C. (1957). Personality and organization, New York: Harper Collins Pub.

Arıcıoğlu, M. A. (1995). Batı ve Japon işletme yönetim anlayışlan, Konya: Selçuk Üniversitesi Sosyal Bilimle Enstitüsü.

Blake, R. \& Mouton, J. (1964). The managerial grid: The key to leadership excellence, Houston: Gulf Publishing Co.

Brazier, D. K. (2005). Influence of contextual factors on health-care leadership, Leadership and Organization Development Juornal, 26(2): 128-140.

Cacioppe, R. (1998). Structured empowerment: An Award-Winning Program at The Burswood Resort Hotel, Leadership and Organization Development Juornal, 19(5), 264-274.

Choi, J. (2006). A motivational theory of charismatic leadership: Envisioning, empathy and empowerment, Journal of Leadership and Organizational Studies, 13.

Drucker, P. (1995). Managing in a time of great change, New York: Truman Talley Books/Dutton.

Efil, İ. (2005). İşletme yönetimi, Bursa: Aktüel Yayınları.

Emet, C. (2006). Personelin güçlendirilme algıları ile örgütsel kültür arasındaki ilişkinin bankacılık sektöründe ampirik olarak incelenmesi, Yüksel Lisans Tezi, Dumlupınar Üniversitesi Sosyal Bilimler Üniversitesi, Kütahya.

Eren, E. (2009). Yönetim ve organizasyon: Çağdaş ve küresel yaklaşımlar, İstanbul: Beta Yayınları.

Eren, E. (2016). Yönetim ve Organizasyon: Çă̆daş ve Küresel Yaklaşımlar, İstanbul: Beta Yayınları.

Gandz, J. (1990). The employee empowerment era, Business Quarterly, Autumn.

Gibson, J., Ivancevich, J. \& Donnelly, J. (1979). Organizations:Bbehavior, structure and proscess, Business Pub. Inc. 
Gümüştekin, G. E. (2015). Personel güçlendirme, içinde N. D. Ergun Özler (Ed.), Örgütsel Davranışta Güncel Konular, (ss. 133-161), Bursa: Ekin Yayınları.

İzzetbegoviç, A. (2013). Doğu batı arasında İslam, İstanbul: Yarın Yayınları.

Jones, G. R. (2004). Organizational theory-desing and change, New Jersey: Pearson Prentice Hall.

Klagge, J. (1998). The empowerment squeeze-views from the middle management position, The Journal of Management Development, 17(8), 548-558.

Koçel, T. (2011). İşletme yöneticiliği, İstanbul: Beta Yayınları.

Lewin, K., Lippitt, R. \& White, R. K. (1939). Patterns of aggressive behavior in experimentally created social climates, Journal of Social Psychology, 10(2), 271-301.

Likert, R. (1961). New patterns of management, New York: McGraw-Hill.

Litreel, R. F. (2007). Influences on employee preference for empowerment practices by the ideal manager in China, International Journal of Intercultural Relations, 31.

McShane, S. L. \& Von Glinow, M. A. (2016). Örgütsel davranış, (Çev. Ed. A. Günsel ve S. Bozkurt), İstanbul: Nobel Yayınları, (Orijinal Bask1: 2016).

Nüvit, O. (2019). İnsan mühendisliği: hayat karşısında insanın kendisi ve çevresi, İstanbul: Alfa Yayınları.

Özel, M. (2016). Yöneticilik dersleri, İstanbul: Küre Yayınları.

Peters, T. J. (1992). Liberation management: Necessary disorganization for the nanosecond nineties, New York: A. A. Knopf.

Sabuncuoğlu, Z. ve Tüz, M. (2001). Örgütsel psikoloji, Bursa: Ezgi Kitabevi.

Sigler, T. H. \& Pearson, C. M. (2000). Creating an empowerment culture: Examining the relationship between organizational culture and perception of empowerment, Journal of Qualty Management, 5, 27-52.

Spreitzer, G. M. (1995). Psyhological empowerment in the workplace: Demensions, measurement and validation, Academy of Management Journal, 38(5), 1442-1465.

Şakar, N. (2013). Yetki-güç ve yetki devri, içinde Koparal, C. ve Özalp, İ. (Ed.), Yönetim ve Organizasyon, (ss. 70-94), Eskişehir: Anadolu Üniversitesi Yayınları.

\section{Extended Abstract}

Today's variable, dynamic and competitive conditions necessitate a more effective management of human resources, which is the most strategic element of organizations. If this is not achieved, organizations will be subject to corruption, entropy and will be driven to failure. The most basic way to prevent entropy and failure is to direct human resources in an efficient, effective and coordinated manner.

Participation is a tool for the healthy functioning of this referral process. Participatory management manifests itself in the form of paying attention to employees' ideas, including them in decisions, sharing authority and spreading to lower levels. Non-participation, which is the opposite of participation, has manifestations such as not sharing authority, taking decisions on its own, not applying to consultation and collective reason, not giving initiative and responsibility. With this aspect, non-participation management; organizations' participation in management, delegation of authority, empowerment of personnel and failure to operate democratic management mechanisms.

The understanding of unattended management, which has dire and vital consequences such as low motivation, decrease in organizational commitment, job dissatisfaction, loneliness, low performance and productivity, is among the most important problems (problems) experienced in organizations. The most important aspects of unattended management in organizations are that employees are unable to participate in the decisions taken, are deprived of the transfer of authority, cannot take initiative and responsibility for their work, and lack a free and democratic organizational environment.

In organizations, the non-participation management problem, which is addressed as participation in management, delegation of authority, empowerment of personnel, liberation of labor and non-use of democratic management practices, may originate from the administrators and the governed, as well as from the organizational and environmental sources. Disease of unattended management has many organizational and personal negative consequences such as low motivation, 
burnout, deterioration of the work environment, loss of efficiency and performance, decreased administrative efficiency, increased resistance to change, decreased organizational commitment and increased intention to quit.

Being sensitive to opposing ideas, treating employees with understanding and tolerance, creating an atmosphere of trust in the organization, including employees in the decisions taken by giving responsibility and initiative are among the ways to prevent this disease.

Again, being aware of the benefits of participation to the organization, building a participatory organizational environment, making decisions with common wisdom, offering a flat working environment to create synergy, adopting a democratic, humane and collective leadership style, giving responsibility instead of using force, focusing on strategy by moving away from control, employees Employment in a flexible and autonomous manner, entrepreneurship, encouragement of entrepreneurship and innovation, creating a healthy communication opportunity, making information accessible, showing a common goal by creating a unity of purpose, establishing an atmosphere of trust by designing responsibility instead of personal benefit, and other solution strategies to eliminate non-participation. can be counted between.

Non-participation management is among the managerial problems that have vital consequences for organizations. However, if the existence of this disease is accepted, it is known what it is, its sources are determined, the consequences are known, and a search for solutions is attempted, it is not an insurmountable administrative problem. Here, in this study, it is tried to present a framework related to the problem in question by referring to what the non-participation management disease is, what types it is, what its causes are, what results it causes and what should be done to prevent it. Thus, not only the non-participation management problem was diagnosed, but also the solutions were tried to be addressed. 